\title{
Peran Orangtua Menyikapi Pornografi Pada Remaja Melalui Komunikasi Efektif
}

\author{
Djudjur Luciana Radjagukguk*1, Yayu Sriwartini² \\ ${ }^{12}$ Universitas Nasional, Jl. Sawo Manila No. 6, Jakarta Selatan \\ ${ }^{2}$ Program Studi Ilmu Komunikasi, Fakultas Ilmu Sosial Dan Ilmu Politik, Universitas Nasional \\ *e-mail : djudjurluciana01@gmail.com1, yayu sriwartini@yahoo.com²
}

\begin{abstract}
The development of the internet has penetrated all lines of modern life. One of the negative effects of internet development is pornography. Indirectly these effects have an impact on children. In fact, this is an opening door for crime, one of child sexual crime in the online realm. The role of parents to prevent children exposed to pornography so as not to become addicted or at least, to identify the characteristics of children who are addicted to pornography. This happens most easily in children who store boredom, loneliness, fear, anger, and stress. In addition, the role of parents becomes greater in supervising children to pay more attention to what children do both inside and outside home, especially used of high technology, such as the internet. So that parents' approach to build effective communication is needed.
\end{abstract}

Keywords: role of parents, pornography, effective communication

\begin{abstract}
Abstrak
Perkembangan internet telah merambah semua lini kehidupan modern. Salah satu efek negatif perkembangan internet adalah pornografi. Secara tidak langsung efek tersebut berdampak pada anak - anak. Fakta, ini menjadi pintu pembuka kejahatan, yang salah satunya adalah kejahatan seksual anak pada ranah online. Peran orangtua untuk mencegah anak terpapar dari pornografi sehingga tidak menjadi kecanduan atau paling tidak, mengenali ciri anakyang kecanduan pornografi. Hal ini terjadi paling mudah pada anak yang menyimpan rasa bosan, kesepian, takut, marah, dan stress. Selain itu, peran orang tua menjadi lebih besar dalam mengawasi anak untuk lebih memperhatikan yang dilakukan anak baik $d i$ dalam dan luar rumah, terutama penggunaan teknologi canggih, misalnya internet. Sehimgga dibutuhkan pendekatan orangtua membangun komunikasi yang efektif.
\end{abstract}

Kata kunci: Peran Orangtua, Pornografi, Komunikasi Efektif

\section{PENDAHULUAN}

Kemajuan teknologi menandai jaman semakin maju, namun ada banyak persoalan yang muncul, salah satunya mengenai pornografi di kalangan anak-anak. Karena itu permasalahan pornografi menjadi perhatian khusus bagi setiap orangtua, terutama pronografi yang menimpa pada usia anak remaja. Sehingga perlu diperhatikan perkembangan setiap anak dalam keseharian. Apa itu pornografi dan bagaimana perkembangan pornografi sekarang ini?

Bentuk porno atau cabul merupakan suatu gambaran yang bisa dilihat melalui tulisan, lukisan, foto, film atau dalam acara televisi yang mengekploitasi seks yang dianggap tidak patut dilihat. Menurut Ridwan (2010; 90) dalam Kamus Besar Bahasa Indonesia, pornografi adalah penggambaran tingkah laku secara erostis dengan lukisan atau tulisan untuk membangkitkan nafsu birahi atau bahan bacaan yang dengan sengaja dan semata-mata dirancang untuk membangkitkan nafsu birahi.

Dewasa ini perkembangan internet merambah di semua lini kehidupan, sayangnya tidak semua memberikan efek positif. Dimana salah satu efek negatif perkembangan internet adalah pornografi. Efek tersebut secara tidak langsung juga mengenai usia anak - anak, dimana 90\% anak - anak terpapar pornografi dari internet di usia 11 tahun. Kehadiran media salah satunya 
secara fisik berpengaruh pada efek ekonomis, efek sosial, efek penjadwalan kegiatan, efek penghilangan perasaan tertentu dan efek perasaan orang pada media tersebut (Rakhmad, 2013: 20). Apa yang harus diwaspadai pada usia anak remaja? Dampak yang dihasilkan dari pornografi. Tentu, diperlukan peran orangtua untuk mencegah agar anak tidak menjadi kecanduan dengan pornografi

Menurut Peri Umar Farouk (2008; 3) berdasarkan survei tahun 2006 yang dilakukan yopteenreviews.com, lembaga survei internet terkemuka dunia menghadapi tantangan pornografi remaja yang serius. Di tahun yang bersangkutan tercatat berkembangnya 100.000 situs yang bermaterikan pornografi anak (usia 18 tahun ke bawah). Rata-rata usia termuda anakanak pengakses pornografi adalah 11 tahun (setara dengan anak kelas 4-5 SD). Dan yang penting jadi perhatian keluarga serta lingkungan adalah kenyataan bahwa $90 \%$ akses pornografi dilakukan ketika atau dengan alasan belajar atau mengerjakan tugas bersama.

Divisi Tumbuh Kembang, Departemen Ilmu Kesehatan Anak Fakultas Kedokteran, dr. Ariani, MKes., SpA(K) bahwa informasi akibat meluasnya penggunaan internet hanya menjadi salah satu faktor utama. Hal lain adalah ketidakpedulian orangtua dalam hal pengasuhan dan tumbuh kembang anak. Perilaku anak remaja yang terkena dampak negatif dari pornografi biasanya lebih cepat dikenali oleh guru mereka di sekolah. dr. Ariani juga menuturkan pernah menjumpai teman anaknya di sekolah yang memperagakan adegan menjurus pornografi, meskipun itu dianggap sebagai bahan candaan.

Tentu saja peran orangtua menjadi lebih besar dalam mengawasi anak untuk lebih memperhatikan semua yang dilakukan baik di dalam dan luar rumah, terutama penggunaan teknologi canggih, yaitu internet. Sehingga dibutuhkan pendekatan melalui komunikasi yang efektif. Orangtua harus mampu mengambil inisiatif dalam membangun komunikasi yang efektif. Banyak cara membangun komunikasi yang efektif sejak dini, tidak harus menunggu anak besar. Karena pola pikir anak bisa saja sudah berubah yang disebabkan faktor lingkungan. Salah satumya, mendengar cerita saat anak pulang sekolah atau saat mereka selesai bermain. Pancing mereka untuk mau cerita apa yang terjadi hari ini.

Saat komunikasi yang efektif telah terjalin antara anak dan orangtua tentu saja akan memberikan keuntungan tersendiri bahkan orangtua bisa memberikan usulan apa yang dapat dilakukan selain bermain gadget. Seperti yang dijelaskan Lely Surayani $(2019 ; 245)$ seorang tokoh "ACIL merupakan tokoh anak-anak yang dijadikan maskot anak cinta lingkungan untuk membangkitkan minat anak-anak belajar tentang lingkungan hidup. ACIL diasosiasikan sebagai anak yang cerdas, riang, proaktif dan selalu ingin tahu. Ia selalu mengajak anakanak lain untuk memperhatikan dan belajar tentang lingkungan. Dengan cara ini diharapkan anak-anak bisa mendapatkan informasi berkaitan dengan alam dan lingkungan hidup, baik berupa pengetahuan umum maupun pemahaman dasar tentang lingkungan". Selain itu, salah satu keuntungannya adalah tidak akan sulit untuk mengawasi anak.

Komunikasi yang efektif juga akan membuat perilaku dan sikap anak menjadi lebih terkendali. Sehingga bentuk komunikasi efektif dibutuhkan sekali dalam kehidupan anak, sangat diharapkan tujuan pengabdian kepada masyarakat ini memberikan pengertian dan pemahaman kepada Ibu-Ibu di Malinjo Pasar Minggu mengenai pencegahan pornografi di media sosial pada anak melalui komunikasi efektif. Hal ini dilakukan dosen dan mahasiswa komunikasi Universitas Nasional mengingat anak-anak membutuhkan pengawasan secara langsung dengan perkembangan teknologi yang semakin canggih. Sehingga kegiatan yang dilaksanakan di Ruang Publik Terpadu Ramah Anak (RPTRA) Malinjo, Jalan Malinjo No 107 Rt 07/ Rw 06 Pejaten Barat Kecamatan Pasar Minggu menjadi hal yang penting karena di sini anak-anak bisa menghabiskan waktu bermain dan bersosialisasi pada hal yang positif. 


\section{METODE}

Pada penyuluhan mengenai pornografi dilakukan beberapa persiapan termasuk dengan adanya konseling untuk peserta. Berdasarkan pendapat dari beberapa informan peran penyuluh sebagai motivator. (Nia Kurniasih dan Dewi Setia; 2018;3)

Menurut Ravik Karsidi dalam Jurnal Penyuluhan bahwa salah satu prinsip pendampingan untuk pemberdayaan masyarakat adalah pengakuan akan pengalaman dan pengetahuan lokal masyarakat. Hal ini bukanlah berarti bahwa masyarakat selamanya benar dan harus dibiarkan tidak berubah. Karena itu memberikan arahan kepada orangtua dengan suatu pengetahuan betapa bahaya gadget.

Adanya sebuah perencanaan yaitu supaya tujuan dapat tercapai dengan baik, perlu disusun suatu rencana tentang jalannya kegiatan-kegiatan. Misalnya, Apa yang harus dilakukan (what), Dimana dilakukannya (Where), Kapan melakukannya (When), Siapa yang melakukan (Who) dan Bagaimana melakukannya (How). Sehingga untuk memudahkan pelaksanaan kegiatan penyuluhan, maka di dalam perencanaan tersebut, perlu disusun hal-hal tersebut.

Dalam kegiatan pengabdian masyarakat ini menggunakan metode pelaksanaan kegiatan penyuluhan yang diterapkan seperrti metoda ceramah dan diskusi mandiri. Sebab metoda penyuluhan yang dipilih harus sesuaikan dengan karakteristik sasaran, sumberdaya yang tersedia dan lingkungan yaitu tempat dan waktu.

Program yang dilakukan berbentuk ceramah dan tanya jawab kepada orangtua terlebih para Ibu yang berada di Ruang Publik Terpadu Ramah Anak (RPTRA) Malinjo Pasar Minggu, mengenai pornografi di kalangan anak-anak karena kecanggihan dari teknologi. Tentunya, hal ini perlu dilakukan agar orangtua waspada apa yang terjadi pada anak-anak yang hidupnya lebih banyak bertemu dengan gadget.

Kedua, rencana kegiatan ini disusun sehingga memungkinkan pelaksanaan program secara efesien dengan menggunakan power point (ppt) dan contoh serta cara-cara terbaik yang dapat dilakukan orangtua terhadap pengetahuan mengenai pornografi. Kemudain ketiga kalender kerja dilakukan pada bulan Oktober 2019.

Sebelum acara dimulai, tim pengabdi telah mempersiapkan terlebih dahulu power point untuk memberikan penjelasan yang berbentuk tulisan dan gambar supaya lebih mudah dipahami para orangtua dalan menerima pesan yang disampaikan Kemudian memutarkan film pendek bagaimana seorang anak asyik dengan gagdetnya membuka situs pornografi saat orangtua sedang tidak memperhatikan.

Pengabdian masyarakat ini dibagi dalam tiga bentuk yaitu sesi pertama dengan memaparkan mengenai pormografi secara "gamblang" kepada para orangtua yang hadir di Ruang Publik Terpadu Ramah Anak (RPTRA) dengan memberikan gambar dan bentuk film serta data yang membuat anak-anak sekarang terpapar dengan pornografi.

Berikutnya memberikan kesempatan kepada para orangtua untuk bertanya dan memulai diskusi dengan tanya jawab. Setelah itu diberikan kesempata untuk konseling kepada orangtua yang masih ingin menceritakan hal-hal yang memerlukan dukungan. Penyuluhan ini dilakukan jam 10.00 WIB sampai jam 14.00 WIB. Dibantu mahasiswa Universitas Nasional dengan kegiatan tanya jawab kegiatan ini berjalan dengan lancar.

\section{HASIL DAN PEMBAHASAN}


Pengabdian kepada masyarakat dilaksanakan pada Hari Kamis 16 Oktober 2019 pukul 10.00 WIB - 14.00 WIB untuk Ibu-Ibu Malinjo Pasar Minggu Jakarta Selatan. Pengabdian ini diikuti oleh sekitar 30 Ibu-Ibu Ruang Publik Terpadu Ramah Anak (RPTRA) Malinjo, serta tempat yang digunakan untuk pelaksanaan penyuluhan ruang aula RPTRA Malinjo.

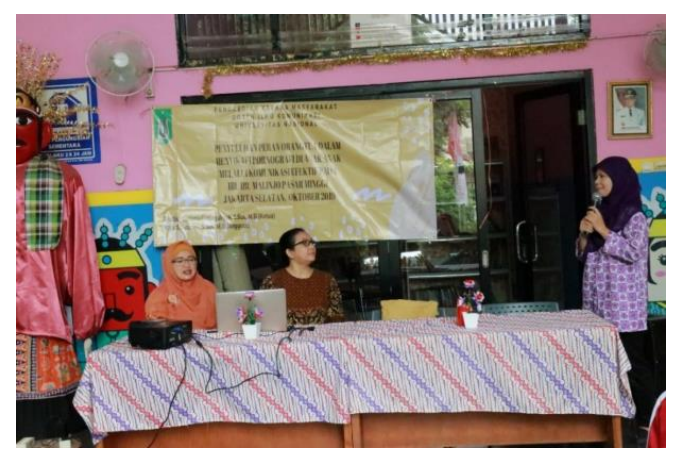

Gambar 1. Sambutan Ibu Nurhartati Ketua Pengurus (RPTRA) Malinjo

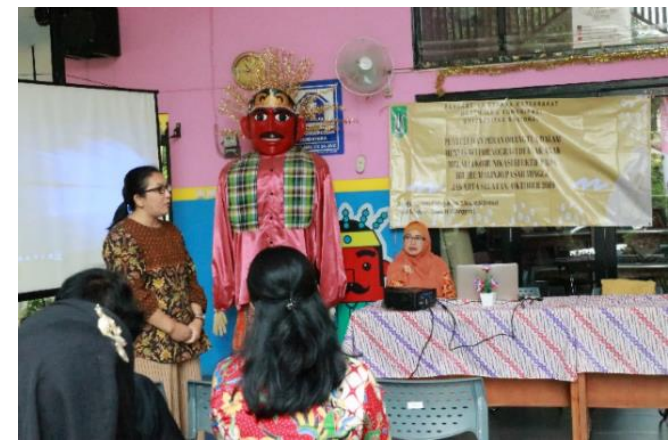

Gambar 2. Narasumber (Djudjur) memberikan penyuluhan

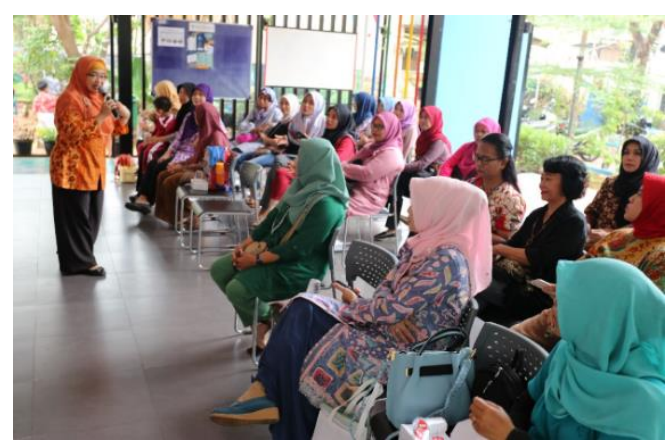

Gambar 3. Narasumber (Yayu) memberikan penyuluhan

Para Ibu-Ibu RPTRA Malinjo sangat antusias sekali mengikuti penyuluhan, karena mereka merasakan pentingnya tema komunikasi efektif pada anak. Tentu saja, hal ini sangat dibutuhkan terlebih dalam memberi pengertian mengenai pornografi. Mudahnya akses internet, bahkan di daerah terpencil sekalipun, membuat orang mudah mengakses pornografi. Sementara para orang tua atau guru, mungkin yang gagap teknologi sehingga mereka tidak membatasi akses internet yang ditonton oleh anak-anaknya.

Sebagai contoh sebuah kasus: ketika melihat tayangan televisi anak putrinya, terkejutlah seorang ibu, ketika putrinya yang masih bersekolah di kelas TK A (Taman Kanak-Kanak), tersipu malu saat melihat adegan mesra di layar televisi. Sang Ibu merasa mendapat serangan penyakit jantung, saat menebak-nebak dalam hati, tentang apa yang yang sedang dipikirkan oleh si anak. 
Kasus berikutnya, Ibu yang lain, yang memiliki putra berusia 7 tahun, juga merasa hampir berhenti jantungnya, saat si anak bergegas ke kamar mandi ketika melihat adegan saling peluk dan cium si sinetron. Apakah anak sekecil itu memiliki dorongan seksual dan suka dengan pornografi/pornoaksi? Astaga, membayangkan saja, sang Ibu sudah merinding. (Ridwan;2010; 93)

Selain itu, kurangnya pemahaman tentang pendidikan seks, justru memperparah kondisi seks bebas ini terhadap remaja karena tidak mendapat bekal pengetahuan tentang bahaya atau dampak dari seks bebas yang mereka lakukan. Faktor kurangnya penanaman nilainilai agama juga turut berperan terhadap kejadian seks bebas.

Kemajuan teknologi ponsel setiap orang bisa menjadi kameraman atau penyebar video. Sekarang ini, tidak sedikit orang yang dengan sengaja mendokumentasikan hal-hal yang sebenarnya merupakan hal yang sangat pribadi, dengan alasan tertentu. Begitu juga, para remaja yang relatif belum bisa berpikir jauh, mereka melakukan hal itu hanya sekedar ingin mendapatkan like atau menjadi viral. Satu hal yang sering luput dari perhatian masyarakat yang ada di lokasi kejadian, misalnya remaja yang memvideokan atau mereka yang seharusnya bisa mencegah terjadinya kejadian tersebut. Dalam banyak kasus, seringkali masyarakat yang seharusnya bisa mencegah, namun malah sering berperan sebagai yang seolah-olah memberi semangat kepada para pelaku.

Seperti yang dijelaskan Ridwan $(2010 ; 101)$ dari beberapa kasus yang ditemui di lapangan, anak mulai mengenal pornografi ketika komunikasi yang tidak baik, tidak terbuka, tidak hangat dan tida nyaman antara orangtua dan anak, secara tidak langsung berpengearuh kepada perilaku menyimpang seperti pornografi. Salah satu contohnya:

"Aku tuh meras kesepian dan kurang kerjaan di rumah. Sudah anak tunggal, e ... orang tua jarang bisa diajak ngobrol santai. Kalaupun sempat berbicara, "hawanya" adalah instruksi melulu, tanpa penjelasan. Psikolog banyak bilang kulaitas pertemuan itu lebih penting daripada kuantitas. Buatku itu gombal! Ngonrol hal-hal yang berkualitas doing, bikin suasana kaku!", alasan lainnya: "Kalau orangtuaku suknya ngeritik anaknya dan tidak pernah memuji. Aku jadi mengindar saja kalau mau diajak ngobrol. Yang bikin malu-maluin adalah sering banget mereka ngeritik aku depan teman-temanku. Kalau teman-teman sudah pulang, gantian deh ortu mengkritik temantemanku itu. Yang katanya, urakanlah, tidak sopanlah sampai ke tampangnya yang tidak pinat. Jadilah ortu di rumah, aku ngumpet aja di kamar."

Fenomena Penyebaran Pornografi Di Indonesia yaitu 97 Persen Anak Indonesia Usia 9-17 Tahun Sudah Terpapar Pornografi (Kementerian Pemberdayaan dan Perlindungan Anak RI). Polri Sebut 236 Kasus Pornografi Terjadi sampai Mei 2019, termasuk pelecehan seksual terhadap anak, usia korban di antara 9-14 tahun dan 90\% dilakukan oleh orang terdekat. (www.cnnindonesia.com).

Fakta miris terjadi di Kabupaten Tulungagung ada anak berusia sembilan tahun sudah sakaw akibat kecanduan pornografi, sehingga jika keinginannya untuk menonton pornografi tidak terpenuhi sang anak akan berguling-guling di lantai. Di antara Agustus 2018 hingga April 2019 ini, Mesin Pengais Konten Negatif (AIS)) Kominfo telah menemukan sebanyak 898.108 konten pornografi. (www.kominfo.go.id ).

Ventje $(2021 ; 61)$ menjelaskan teknologi internet telah membawa materi pornografi yang dulu hanya bisa diakses melalui buku maupun video ke dalam dunia cyber yang luas. Semua orang, tanpa melihat usia, bisa mengakses materi pornografi dari rumahnya asalkan ada komputer atau handphone dan akses internet. Bayangkan, cukup dengan mengetikkan kata kunci sex, porn, atau nudes pada mesin pencari, maka akan ditampilkan ribuan situs yang bisa dikunjungi dengan mudah. Banyaknya situs pornografi lokal dan internasional yang ada di 
internet telah membuat banyak pihak, terutama orang tua, khawatir dengan perkembangan anakanak yang merupakan generasi penerus bangsa.

Beberapa bentuk Ragam pornografi secara muatan yaitu soft core, yang artinya hadir materi pornografi berupa ketelanjangan, scene atau adegan yang memberikan kesan terjadinya hubungan seks dan seksual secara tersimulasi. Hard core yaitu dalam bahasa Indonesia sering dikenal dengan sebutan triple X (X rated), materi orang dewasa dan materi seksual yang secara eksplisit terpampang, seperti halnya penampilan aktivitas alat genital dan aktivitas seksual. Snuff adalah adegan kekerasan seksual yang bisa benar-benar merenggut nyawa. Obscenity (kecabulan), bilamana sesuatu tersebut mempertontonkan materi seksualitas yang menentang secara ofensif batas dari kesusilaan dalam masyarakat, yang tidak layak dipertontonkan.

Selain itu masih ada ragam pornografi berdasarkan ragam media, misalnya pornografi di media cetak (koran, majalah, tabloid, novel) berbentuk tulisan, gambar, atau sketsa. Pornografi di media audio (radio, party line), contohnya dalam konsultasi tentang seks. Bentuknya suara, kata-kata/kalimat pornografi di media audio visual (TV), bentuknya: film/sinetron berupa adegan, ucapan. Lagu-lagu berupa lirik. Di iklan berupa adegan, ucapan. Sementara pornografi di media luar ruang yaitu; 1) Billboard atau papan reklame, biasanya menampilkan model yang berpenampilan seksi; 2) Poster-poster/spanduk-spanduk/baliho profil film layar lebar yang terpampang di bioskop-bioskop; 3) lukisan atau gambar seronok yang biasa terpampang di badan belakang truk-truk.

Mengapa anak-anak remaja terpengaruh pornografi? Tentu hal ini karena 1) Perkembangan tubuh, yakni terjadinya kematangan organ-organ seksual, sehingga sangat sensitif terhadap rangsangan seksual di sekitarnya; 2) Kurangnya pemahaman tentang pendidikan seks justru membuat remaja tidak mendapat bekal pengetahuan tentang bahaya atau dampak dari seks bebas yang mereka lakukan; 3) Mudahnya akses massa, bahkan di daerah terpencil sekalipun, membuat orang mudah mengakses pornografi.; dan 4) Seringkali orang dewasa yang seharusnya bisa mencegah, namun malah sering berperan sebagai yang seolaholah memberi semangat kepada para pelaku (dorongan teman).

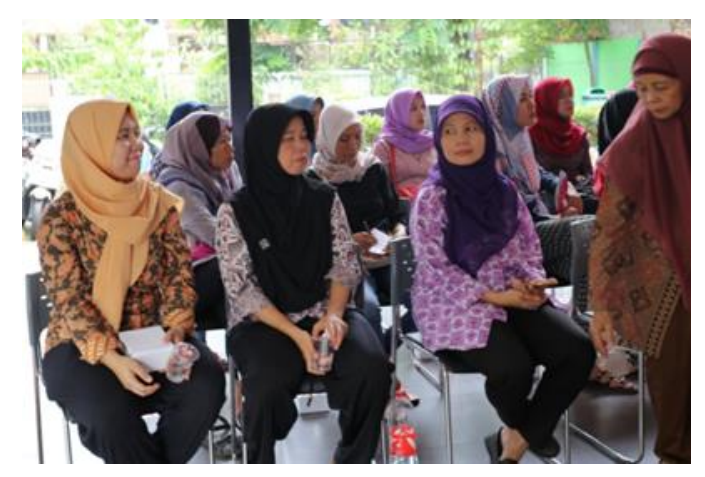

Gambar 4. Saat ibu-ibu mendengarkan dengan seksama

Keseriusan para Ibu-Ibu RPTRA Malinjo dengan antusias bertanya mengenai dampak pornografi pada anak. Sebenarnya, beberapa faktor lain yang merubah persepsi seksual remaja adalah akses media massa, faktor lingkungan, pergaulan, kurangnya bimbingan orang tua terutama ajaran agama baik dirumah maupun disekolah (Miftahul \& Khofiyah, 2017). Anak remaja memerlukan media sebagai informasi yang dapat menjelaskan perkembangan reproduksi dan masalahnya sumber utama media informasi yang dicari oleh remaja adalah sekolah dan 
media massa. Meskipun pesan-pesan yang ada di media massa berisi informasi yang salah, namun hal tersebut dianggap fakta oleh remaja. Hal ini mungkin terjadi karena media massa memberikan gambaran lebik baik mengenai keinginan dan kemungkinan yang positif mengenai seks dibandingkan permasalahan dan konsekuensinya. Media yang paling sering digunakan adalah internet dan televisi.

Dampak yang mungkin terjadi pada anak-anak akibat pornografi
(https://www.sehatq.com/artikel/dampak-buruk-pornografi-pada-anak-anak)
diperhatikan pertama kecanduan yaitu berbagai konten pornografi yang muncul melalui iklan, media sosial, games, film, video klip, ataupun tontonan di atas awalnya akan membangkitkan rasa penasaran terlebih dahulu pada anak, bahkan saat tidak sengaja melihat sekalipun. Rasa penasaran inilah yang menjadi dorongan anak-anak untuk melihat lebih banyak konten pornografi lainnya. Selain itu, kecanduan ini dipicu oleh pengeluaran hormon dopamin pada otak sehingga akan menimbulkan perasaan bahagia ketika menonton konten pornografi. Bila tidak segera dicegah, bukan tidak mungkin kecanduan terhadap pornografi dapat terjadi pada anak.

Kedua merusak otak ini yang berbahaya, pornografi dapat merusak otak anak, tepatnya pada salah satu bagian otak depan yang disebut Pre Frontal Cortex (PFC). Hal ini disebabkan karena bagian PFC yang ada di otak anak belum matang dengan sempurna. Jika bagian otak ini rusak, maka dapat mengakibatkan konsentrasi menurun, sulit memahami benar dan salah, sulit berpikir kritis, sulit menahan diri, sulit menunda kepuasan, dan sulit merencanakan masa depan.

Ketiga, keinginan mencoba dan meniru, dampak lain yang dirasakan anak setelah melihat pornografi adalah keinginan untuk mencoba dan meniru. Ini berkaitan dengan terpengaruhnya mirror neuron. Mirror neuron adalah sel-sel otak yang mampu membuat anak seperti merasakan atau mengalami apa yang ditontonnya, termasuk pornografi. Hal ini dapat mendorong anak untuk mencoba dan meniru apa yang dilihatnya.

Keempat, mulai melakukan tindakan seksual, jika tidak diawasi, anak-anak yang terpapar pornografi ini bisa saja mencoba melakukan tindakan seksual untuk mengatasi rasa penasarannya. Apalagi jika mereka sudah remaja, jika tidak diberikan pendidikan dan pemahaman seksual yang baik, keinginan melakukan tindakan-tindakan seksual sulit dicegah.

Tidak hanya itu efek paparan pornografi pada kehidupan anak yaitu bila anak yang sudah terpapar materi pornografi bisa mengalami masalah mental dan terganggu tumbuh kembangnya. Pornografi mempengaruhi perilaku anak. Anak akan memiliki pandangan buruk tentang perempuan, melakukan kekerasan seksual, menjadi pelaku seks dini, kecanduan, penurunan prestasi sekolah, dan depresi.

Namun, seiring dengan perkembangan zaman yang semakin maju dan internet sudah melekat pada kehidupan anak-anak, paparan pornografi yang tersebar bebas dan luas di dunia maya wajib diwaspadai. Dengan kemudahannya untuk diakses, maka tidak menutup kemungkinan jika anak turut menonton film porno di smartphone-nya. Hal tersebut juga dapat di dukung oleh pengaruh dari teman pergaulan di sekolah.

Sehingga, yang dibutuhkan anak yaitu perhatian dengan komunikasi. Saat komunikasi yang efektif telah terjalin antara anak dan orang tua maka banyak hal positif yang diperoleh orangtua. Salah satunya, orangtua tidak akan sulit untuk mengawasi anak. Komunikasi yang efektif juga akan membuat perilaku dan sikap anak menjadi lebih terkendali. Tentunya komunikasi efektif memberikan manfaat yaitu bahwa sebuah pesan dapat tersampaikan dengan baik, kedua pesan yang disampaikan sesuai dengan yang dimasukan dan diharapkan, selain itu mengurangi terjadinya kesalahpahaman serta konflik atau pertengkaran dapat terselesaikan secara cepat dan hubungan akan terjalin dengan erat. 
Seperti yang dijelaskan Edy Suryadi $(2010 ; 271)$ komunikasi anak dengan orang tua dan guru berdasarkan perasaan subjektif dan pada usia remaja pada dasarnya penghayatan tersebut merupakan akumulasi kesan dan pengalaman sepanjang hidupnya. Pada usia remaja, lingkungan kelurga dan sekolah tetap tampil sebagai faktor yang signifikan bagi perkembangan psikologis individu, bahkan pada fase inilah individu mulai menunjukkan identitas dirinya. Keinginan untuk berdiri sendiri dan lepas dari ketergantungannya terhadap orang tua dan guru, disatu pihak, dan kekurang mampuannya untuk berdiri sendiri, dilain pihak, seringkali menimbulkan konflik pribadi.

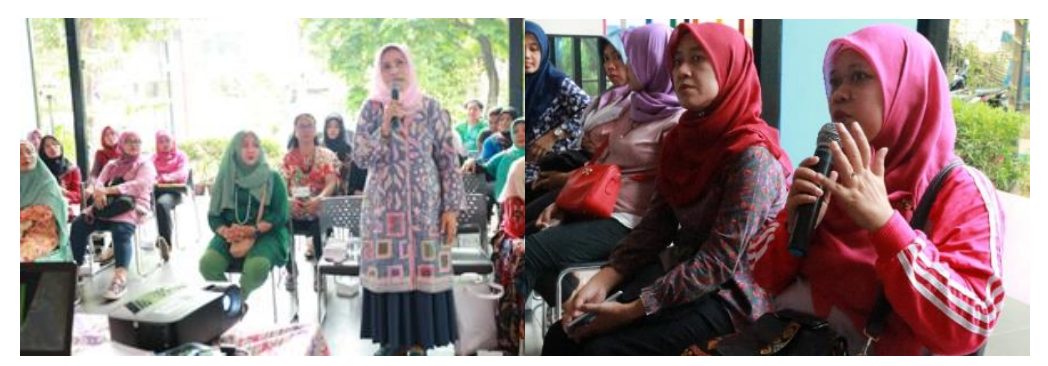

Gambar 5. Saat peserta bertanya

Keluarga tempat pendidikan pertama bagi anak, karena itu komunikasi orang tua sangat penting dalam rangka pembentukan karakter seorang anak. Sehingga, komunikasi efektif dapat dilakukan dengan melatih kemampuan komunikasi non-verbal pada anak artinya, komunikasi non-verbal lebih memiliki peranan kuat dibanding komunikasi verbal. Komunikasi non-verbal terdiri dari gerak tubuh, mimik wajah, penampilan fisik, sentuhan, jarak personal, lingkungan, dan bahkan kediaman. Orangtua harus mampu memberikan sentuhan-sentuhan yang hangat bagi anak. Satu hal yang perlu diperhatikan, komunikasi non-verbal memiliki peranan yang kuat, perlu terus berlatih untuk mengontrolnya. Misalnya, mengontrol mimik wajah. Mungkin saja wajah memang cenderung seperti orang tidak ramah sehingga kerap membuat orang lain salah paham. Sehingga dapat melatih dengan sering-sering senyum di depan kaca atau senam wajah supaya lebih rileks.

Kedua, menjadi orangtua sebagai pendengar yang baik, ketika anak bercerita kita mau mendengarkan apa yang menjadi keluh kesahnya, bahkan sampai cerita mereka berakhir sehingga anak-anak mengangap orangtua adalah teman dan sahabatnya. Ketiga, sebagai orangtua dapat berbicara dengan jelas. pembicaraan yang mengalir dengan jelas membuat anak-anak akan lebih terkesan bahwa mereka akan menganggap bahwa orangtua adalah lawan bicara yang mampu memberikan pesan yang membangun dan menghibur diri mereka.

Keempat, memperhatikan tata krama dalam berbicara. Ketika berbicara dengan kata atau kalimat yang disampaikan dengan tutur kata yang berurutan, jelas, terperinci namun enak didengar akan membuat anak-anak merasa nyaman berbicara. Hindari kata - kata yang terkesan menyinggung hal - hal pribadi. Terlebih apabila anda memotong pembicaraan anak hanya akan meninggalkan kesan buruk dimatanya. 
Kelima, melakukan kontak mata yang lama, dilakukan secara terus menerus akan memberikan kesan tersendiri bagi anak. Kesan yang dapat ditimbulkan bisa berupa perhatian orangtua terhadap apa yang disampaikan anak, memberi kesan bahwa selaku orangtua tertarik dengan isi percakapan tersebut. Selain itu, senyum sebagai indikator ketertarikan, artinya senyum merupakan hadiah teristimewa yang dapat orangtua berikan secara cuma - cuma. Dan dalam percakapan, ketika orangtua tersenyum kepada anak saat mereka melontarkan hal - hal lucu dan menarik, menjadi nilai tersendiri bagi anak. Tersenyum sejatinya mampu menghidupkan dan mengembangkan hubungan baik antara orangtua dan anak.

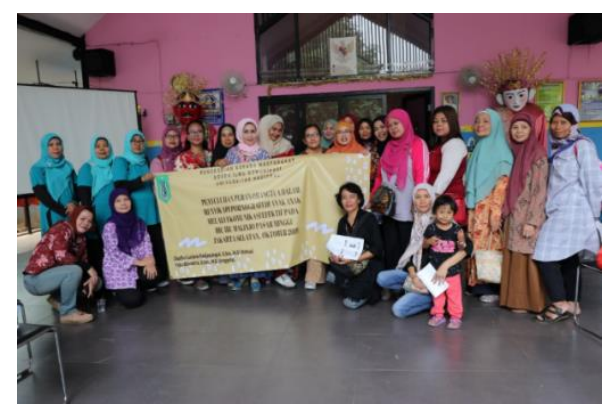

Gambar 6. Saat berfoto bersama

\section{KESIMPULAN}

Tentunya, program pengabdian kepada masyarakat kepada Ibu-Ibu RPTRA Malinjo berjalan dengan baik dan diikuti dengan penuh semangat. Terlebih para orangtua memang membutuhkan pengetahuan yang lebih dalam lagi mengenai penanganan hal-hal berkomunikasi kepada generasi muda dengan kecanggihan teknologi yang semakin berkembang. Karena tidak semua orangtua mampu untuk dapat memainkan alat komunikasi seperti halnya handphone yang sudah dilengkapi dengan berbagi fitur. Namun, cara dan tehnik berkomunikasi memang sangat dibutuhkan dalam menghadapi perkembangan anak dengan jaman yang semakin canggih melalui teknologi. Anak-anak akan semakin berkembang mengikuti perkembangan teknologi dan kemampuan orangtua mengharuskan dapat mengerti dengan melesatnya teknologi. Orangtua dapat memberikan kuota pada anak dengan membatasi bahwa internet untuk kebutuhan belajar. Selain itu orangtaua bisa memberikan batasan pada anak-anak waktu menggunakakan gadget.

Tentunya kegiatan pengabdian kepada masyarakat ini sangat diharapkan Ibu-Ibu di RPTRA Malinjo menjadi satu kelanjutan yang berkesinambungan dengan didukung orang-orang yang paham dengan hukum. Karena, para ibu ingin tahu bagaimana hukum yang berlaku jika terjadi satu hal pada anak-anak yang terpapar dengan pornografi. Harapan ke depan mampu membuat suatu bentuk konseling bagi para ibu di RPTRA Malinjo dan juga bagi anak-anak yang menjadi korban dari pornografi. Anak-anak adalah generasi bangsa, mereka tentu ingin seperti anak-anak pada umumnya bermain, bercanda selayaknya dunia anak-anak. Sebagai orangtua tentu saja harapannya ingin agar anak dapat tumbuh dan berkembang dan menjadi generasi yang baik.

\section{UCAPAN TERIMAKASIH}

Ucapan terima kasih penulis haturkan kepada Ketua LPPM Universitas Nasional Jakarta Prof. Dr. Ernawati Sinaga, M.S., Apt berikut jajarannya yang telah memberi dukungan moril dan finansial terhadap pengabdian ini sehingga dapat terselenggara dengan baik dan lancar. Semoga ke depan penulis dapat memberikan hal yang terbaik. 


\section{DAFTAR PUSTAKA}

Suryani, L., Usman, A., Tute, K. (2019). PKM Pelatihan Kelompok Anak Cinta Lingkungan Kabupaten Ende Dalam Pegelolaan Limbah Organik Dan Anorganik Berbasis 3r Untuk Mengeskalasi Nilai Ekonomis Barang Sebagai Bekal Wirausaha Mandiri, DINAMISIA-Jurnal Pengabdian Kepada Masyarakat Vol. 3, No. 2, Desember 2019, Hal. 244-251 https://journal.unilak.ac.id/index.php/dinamisia/article/view/3679/1990

Suryana, K.N., \& Ningsih, D.S. (2018). Peran Penyuluh Pertanian Dalam Pemberdayaan Kelompok Tani ( Studi Kasus Kelompok Tani Subur Di Desa Karang Agung Kabupaten Bulungan ), Jurnal Borneo Humaiora, at ojs.borneo.ac.id e-ISSN 2599-3305 p-ISSN 2615-4331 Diterbitkan Februari 2018 Halaman 1-6 http://ojs.borneo.ac.id/ojs/index.php/humaniora

Rahmania, Tia. (2017). Persepsi Pornografi Pada Anak (Studi Pendahuluan Pada Siswa Kelas 5 Sekolah Dasar Islam "X"), INQUIRY Jurnal Ilmiah Psikologi, Vol. 8 No. 1, Juli 2017, hlm 55-74. http://journal.paramadina.ac.id/index.php/inquiry/article/viewFile/129/71

Jeremias, Ventje. (2012). Upaya Melindungi Anak-Anak Dari Pornografi di internet, Jurnal $\begin{array}{lllll}\text { Sosioteknologi } & \text { Edisi } & 25 & \text { April }\end{array}$ file://C:/Users/USER/Documents/WFH\%20UNAS/1089-3426-1-SM.pdf

Suryadi, Edy. (2010). Model Komunikasi Efektif Bagi Perkembangan Kemampuan Berpikir Kreatif Anak, Jurnal Ilmu Komunikasi, Volume 8, Nomor 3, September - Desember 2010, halaman 263 - 279 https://media.neliti.com/media/publications/100116-ID-model-komunikasi-efektifbagi perkembang.pdf

Karsidi, Ravik. (2007). Pemberdayaan Masyarakat Untuk Usaha Kecil Dan Mikro (Pengalaman Empiris di Wilayah Surakarta Jawa Tengah), Jurnal Penyuluhan IPB, ISSN: 1858-2664, September 2007, Vol. 3 No.2. https://media.neliti.com/media/publications/8595-IDpemberdayaan-masyarakat-untuk-usaha-kecil-dan-mikro-pengalaman-empiris-diwilaya.pdf

Miftahul, R., \& Khofiyah, N. (2017). Hubungan Akses Media Pornografi Dengan Persepsi Remaja Tentang Seksual.

Rahkmad, Jalaludin. (2013). Psikologi Komunikasi, PT Remaja Rosdakarya. Bandung.

Sanjaya R Wibhowo, C. Adi A. (2010). Parenting Untik Pornografi di Internet. PT Elex Media Komputindo, Jakarta.

Razak. Abdul. Subagio.Gunawan, (2000), Debat Besar Pornografi, Harian Umum Pikiran Rakyat.

Rahmawati, Dina. (2016). Orangtua Perlu Waspada! Inilah Dampak Buruk Pornografi pada Anakanak. https://www.sehat.com/artikel/dampak-buruk-pornografi-pada-anak-anak 